\title{
Family's Role in Helping Drug Abuser Recovery Process
}

\author{
Devy Mulia Sari ${ }^{1)}$, Mochammad Zainal Fatah ${ }^{1,2)}$, Ira Nurmala ${ }^{1)}$ \\ 1 Department of Health Promotion and Behavior Science, Faculty of Public Health, Universitas \\ Airlangga, Surabaya, Indonesia \\ Corresponding directed to e-mail: devymuliasari@yahoo.com
}

\begin{abstract}
Background: The National Narcotics Board or Badan Narkotika Nasional (BNN) survey results found the prevalence of drug abuse in 2015 amount 42,900 people, and an increase of $20.84 \%$ in 2016, which amounted to 51,840 people. As a result of drug abuse, drug abusers often experience health problems both physically and mentally due to the influence of drugs or the environment that makes drug abusers depressed. One of the health treatments for drug abusers that can be done to motivate drug abusers is to provide family support. The family is a source of social support because, in family relationships, mutual trust is created. Objective: This research was conducted to determine how the family's role based on Kroenke helped to recover the health of drug abusers from deciding to stop drug abuse. The government can later consider this research's benefits in creating a family-based drug abuse prevention and recovery program. Methods: This study uses a review of international articles. The articles used are twenty articles published in the last ten years. Result: Research shows that the family's role in helping recovering drug users' health drug users' health is different but still has the same goal. Support provided is based on the cause of individuals to commit drug abuse. Support could be provided in the form of assessment support, instrumental, informational, and social. A good family role's functioning makes the recovery process more effective because an addict will feel motivated by their support. Conclusion: The research conducted that the family's role is essential for the recovery of the health of drug addicts, providing a stimulus for change to stop drug abuse. The family's ability and function in explaining the addict's self-control varies according to how the response and the intensity of family support provided to the addict.
\end{abstract}

Keywords: drugs, drug abused, family role.

\section{INTRODUCTION}

Drug abuse remains a threat to society and the government. This problem arises because the rate of drug abuse in Indonesia is still very high. Drug abuse (narcotics, psychotropics, and other hazardous substances) accompanied by negative implications and impacts is a problem at the national and international level that threatens a society's life. It results in the weak resilience of a nation and country (Bash, 2015)

A report from the world body dealing with narcotics and drugs, the United Nations Office on Drugs and Crime (UNODC), states that $5 \%$ of the world's total population has ever tried drugs. Data in 2015 explained that the increase in drug abuse also occurred in several countries that are members of the Association of Southeast Asian Nations (ASEAN), especially Indonesia. Of the $100 \%$ of narcotics transactions in the
ASEAN region, $40 \%$ are in Indonesia (United Nations Office on Drugs and Crime, 2018)

The handling conducted by the government in dealing with the problem of narcotic abuse, namely by issuing Law No. 35 of 2009 on Narcotics, and Law No. 36 of 2009 on health, which describes the actions on narcotic abusers and addictive substances (Undang-Undang Republik Indonesia Nomor 36 Tahun 2009 tentang Kesehatan, 2009; Undang-Undang Nomor 35 Tahun 2009 tentang Narkotika, 2009). There is also a Government Regulation No. 25 of 2011 on the Implementation of Mandatory Reporting of Drug Abusers. The regulation discusses that the government urges the public to report drug abusers to the recipient institutions must report (IPWL) around the residence area (Peraturan Pemerintah No. 25 Tahun 2011 tentang Pelaksanaan Wajib Lapor Penyalahguna Narkoba, 2011; Sari Wulan Rohmah, 2019) This study explains that 
the government's support and efforts in dealing with drug abuse problems already have a written regulation (Dinilah, 2017)

The government's seriousness in building rehabilitation facilities in each area is concrete evidence to deal with drug abuse. The duration of rehabilitation is carried out in about three months to one year. The duration is determined by each individual's motivation and the social support of those around him. It takes social support for drug abusers as one of the motivations to recover from drug abuse (Inassa, 2019)

Social support is an emotional form provided by individuals and groups to other individuals. Social support can be a sense of attention, compassion, help, and a form of support that includes assessment, instrumental, informational, or emotional support (Kroenke et al., 2006).

One social support source is family, where a family is a place for individuals to grow and develop since childhood. Physical and psychological needs can be met from the family environment because it is the closest environment (former drug abuser). The family in question is the core family, consisting of the father, mother, and son (Heaney and Israel, 2018). A core family is considered a social system because social elements include beliefs, feelings, goals, rules, positions and roles, levels, sanctions, powers, and facilities. If the family can apply the social element, then the drug abuser will feel if he is noticed and allow the individual to stop abusing drugs (Ingram, 2005).

Relationships in a family are social support created because of mutual trust. Families for individuals can be considered a collection of expectations, a place to tell stories, a place to ask questions, and a place to issue complaints if they are recovering (Orr, Elliott and Barbour, 2014). Therefore, this article will discuss family support in carrying out its role to help a drug abuser.

\section{METHODS}

Reviews of this literature are searched using electronic databases such as Pro-Quest, Google Scholar, Google Scholar, PubMed, Science Direct, IJERN, and DOAJ. Literature reviews are conducted on articles published in the last ten years. Keywords used to search are family support, drug abusers, drug abuser rehabilitation, and drug abuse mental health care.

Thirty-five scientific articles were obtained, then selected twenty articles in accordance with the criteria that have been set to compile a review of the literature. The inclusion criteria of the selected article is an international article and discuss the relationship between social networks. The study targeted specific health behaviors, including alcohol and drugs. This literature study analyzes what programs have been applied to recover drug abusers carried out by the family.

\section{RESULTS AND DISCUSSION}

Family support is a process in life that happens all the time. Families have different traits and types of support in different stages of the life cycle. Conceptualization of family support as family coping, both external and internal support. External support includes friends, employers, neighbors, social groups, places of worship, and health practitioners. Internal social support includes the support of a biological family, husband, or wife. The attitude that the family should build toward drug abusers is to provide support to the treatment program. The ability of family members to remind abusers of honesty until the end of the rehabilitation period has a critical role for individual success (Rowe, 2012).

Providing support to family members who abuse drugs cannot be done without understanding the problems faced. These understandings include an understanding of the mindset, attitude patterns, and patterns of drug abusers. This understanding aims to allow the family to provide motivation, attention, and compassion that the family never lacked or never given. A healthy family will make qualified family members intellectually, mentally, and spiritually (Yunitasari, 2018).

Families need to provide a wide variety of information about drugs. The information can range from the dangers of using drugs and their impact on drug abusers to ways to overcome drug addiction. Support in the form of this information will make former drug abusers think positively about the impacts 
of using drugs. This support is also expected to allow individuals to stop and not use drugs anymore, given the longterm impact of drug use is that it can destroy the future of individuals (Sanders, 2000).

Family support can provide a place for drug abusers to pour out their hearts, helping individuals during the recovery process. The recovery process time also depends on the condition of the drug abuser. This statement is in line with other studies that explain that the intensity of family support provided will affect the healing process of drug abusers (Jackson et al., 2011).

Social support can be grouped into several components (Kroenke et al., 2006). These components include emotional, instrumental, informational, assessment support.

\section{Emotional Support}

Emotional support can include feelings and emotional closeness between drug abusers and families (Birtel, Wood and Kempa, 2017; Li and Ma, 2018) Through this support, the emotional attachment will be obtained by drug abusers to create a sense of security. This kind of social support is often obtained from a life partner, close family, or even close friends and relatives. Families with harmonious relationships can reduce the risk of drug abuse (Darie, 2015)

Drug abusers can be restored through a lengthy rehabilitation process and with the support of their families and the environment. Drug abusers who have gone through the rehabilitation period can relapse or relapse if they do not get emotional support from the family (Yunitasari, 2018)

\section{Instrumental Support}

The help obtained directly by drug abusers from family members helps overcome shame and be open with trusted people to stop abusing drugs (McCann and Lubman, 2018). Financial assistance and opportunities to provide jobs will positively impact the mental health of drug abusers (Tomori et al., 2014).

Real support from the family is when the family can appreciate the opinion and willing to listen to complaints from drug abusers and take good care when the drug abuser relapses. Family support can help achieve practical goals and real goals (Baker and Kim, 2019).

\section{Informational Support}

Family members can give explanations to drug abusers about the situation and problems faced by drug abusers. This support can be either advising or explaining how to be good. Families who provide informational support in psychoeducation to drug abusers will help their healing process (Denomme and Benhanoh, 2017).

Information related to drug service agencies' existence for drug abusers will benefit drug abusers to get the proper treatment (Ritanti et al., 2017). The information provided regarding treatment for drug abusers will improve their wellbeing (Rasdianah and Nur, 2018).

\section{Assessment Support}

Family attitudes that are always cornered, brought up in the past, are often the cause of recurrence (Smestha, 2015). Assessment support to drug abusers, such as giving a little trust and mentoring, will provide a sense of security to help them during the recovery period.

Social networks that can accept drug abusers and do not provide negative stigma will positively impact drug abusers (Montgomery et al., 2020). Similarly, when the family provides positive stimulation in encouragement, then drug abusers who have received themselves first will give a positive response (Nurhidayati and Nurdibyanandaru, 2014). When the social environment responds negatively without reinforcing drug abusers, it will cause anxiety and symptoms of depression (Franco and Carter, 2019).

Table 1. Summary of Twenty Articles on Family Support for Drug Abusers

\begin{tabular}{|c|c|c|c|c|}
\hline No & Authors & Title & Methods & Results \\
\hline 1. & $\begin{array}{l}\text { Harwin et al., } \\
2019\end{array}$ & $\begin{array}{l}\text { Tension and } \\
\text { Contradiction in } \\
\text { Family Court } \\
\text { Innovation with High- } \\
\text { Risk Parents: The } \\
\text { Place of Drug } \\
\text { Treatment Courts in }\end{array}$ & $\begin{array}{l}\text { This study uses an } \\
\text { observational design } \\
\text { that looks from } 3 \\
\text { countries, namely the } \\
\text { United States, United } \\
\text { Kingdom, and } \\
\text { Australia. }\end{array}$ & $\begin{array}{l}\text { - The family's drug } \\
\text { treatment has spread to } \\
\text { the UK, Australia, and } \\
\text { Northern Ireland. } \\
\text { International research has } \\
\text { found that the treatment } \\
\text { of the elderly has a more }\end{array}$ \\
\hline
\end{tabular}




\begin{tabular}{ll}
\hline No Authors & \multicolumn{1}{c}{ Title } \\
\hline & $\begin{array}{l}\text { Contemporary Family } \\
\text { Justice }\end{array}$ \\
2. Ritanti et al., & $\begin{array}{l}\text { A Phenomenological } \\
\text { Study of Families } \\
\text { with Drug-Using } \\
\text { Children Living in the } \\
\text { Society }\end{array}$ \\
& $\begin{array}{l}\text { 3. Li et al., 2013 } \\
\text { Mental health and } \\
\text { family relations } \\
\text { among people who } \\
\text { inject drugs and their } \\
\text { family members in } \\
\text { Vietnam }\end{array}$
\end{tabular}
Vietnam

4. Birtel, Wood and Kempa, 2017
Stigma and Social Support in Substance Abuse: Implications for Mental Health and Well-Being
The subjects of this study were 64 who were included in substance abuse (alcohol, drugs) and aged between 18-64 years. The design of the research is a case study.

5. Zhang et al., The Impacts of Family 2019

\section{Treatment Drug \\ Court On Child \\ Welfare Core}

Outcomes: A Meta-

Analysis

\section{Bermas and Masooleh, 2011}

7. Yusay and Canoy, 2019 safety outcomes. The design of the research is phenomenology.
Review and
Comparison of Affective Family Factors in Prevention of Drug Abuse in View of University Masters, Mental Health Specialist, and Families Healing the Hurt Amid the Drug War: Narratives of Young Urban Poor Filipinos in Recovering

This study uses a descriptive phenomenological qualitative design. Many participants were recruited for research using snowballing sampling techniques.

The study used a crosssectional design and sampled 83 families.

Results
significant impact than
regular treatment.
Concludes that the role of
the family as a new
paradigm for addressing
risky parenting and
influencing systemic
change

The medicines service agency commissions public health nurses to act as advisers and advocates to help families manage and address their problems.

- The level of behavior of people who abuse drugs is meaningfully associated with higher symptoms of depression.

- Lower family relationships pose a substantial risk of drug abuse.

- Develop strategies that increase the role of families in supporting behavioral change among people who inject drugs.

- Social support is beneficial for combating the negative impacts of stigma and shame that internalize mental health and wellbeing.

- The synthesized findings reinforce the evidence for implementing and expanding Family Treatment Drug Courts (FTDC) to serve caregivers who abuse substances in the child welfare system. (eight) studies on child Research design includes phenomenology and purposive sampling.
design - Families have an essential role to play in preventing the misuse of narcotic drugs at the initial, secondary, and third levels.
- Experts consider that this family is more critical in reducing the misuse of narcotic drugs.
The number of samples taken is as many as 13 subjects. The research design used is the case study.
- Drug users position themselves in three different ways: "I am used to it," "I am ignored," “I am angry and hurt." After 


\begin{tabular}{ll}
\hline No $\quad$ Authors & \multicolumn{1}{c}{ Title } \\
\hline & $\begin{array}{l}\text { Families with } \\
\text { Parental Drug Use }\end{array}$ \\
& \\
8. Franco and & $\begin{array}{l}\text { Discrimination from } \\
\text { Family and Substance } \\
\text { Use for Multiracial } \\
\text { 9. Li and Ma, }\end{array}$ \\
2018 & $\begin{array}{l}\text { Individuals } \\
\text { The Analysis of a } \\
\text { Drug Transmission } \\
\text { Model with Family } \\
\text { Education and Public } \\
\text { Health Education }\end{array}$
\end{tabular}

10. Darie, 2015

Child's Exposures to Emotional Neglect in Drug users Families

11. Zamani et al., Family Functioning, 2014 Cognitive Distortion and Resilience among Clients under Treatment in Drug Rehabilitation Centres in Malaysia

12. Ghasemi et al., 2018

13. McCann and Lubman, 2018
The effect of an Education Program based on the Family-Centered Empowerment Model on Addiction Severity Among Methamphetamine Users

Help-seeking Barriers and Facilitators for Affected Family Members of a Relative with Alcohol and other Drug Misuse: A Qualitative Study
The study used a crosssectional design involving 466 subjects.

This research is qualitative research. The study focused on populations over the age of 15 .

The subjects in this study were 18 years old using the Freiburg personality inventory method.

The subjects used in this study were 463 subjects.

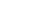




\begin{tabular}{|c|c|c|}
\hline No & Authors & Title \\
\hline 14. & $\begin{array}{l}\text { Denomme and } \\
\text { Benhanoh, } \\
2017\end{array}$ & $\begin{array}{l}\text { Helping Concerned } \\
\text { Family Members of } \\
\text { Individuals with } \\
\text { Substance Use and } \\
\text { Concurrent Disorders: } \\
\text { An Evaluation of a } \\
\text { Family Member- } \\
\text { Oriented Treatment } \\
\text { Program }\end{array}$ \\
\hline 15. & $\begin{array}{l}\text { Jackson et al., } \\
2011\end{array}$ & $\begin{array}{l}\text { Challenges and } \\
\text { Opportunities to } \\
\text { Integrating Family } \\
\text { Members of Injection } \\
\text { Drug Users into Harm } \\
\text { Reduction Efforts } \\
\text { within the Atlantic } \\
\text { Canadian Context }\end{array}$ \\
\hline
\end{tabular}

The large sample consisted of 125 individual family members with

Substance Use and Concurrent Disorders (SUCD), of which 97 participated

in treatment programs, and 28 were used as comparison groups.

The method in this study is a qualitative approach involving 115 Drug Injections (IDU).
Results

and are diligent in helping

the search to recover from alcohol and other drug addictions.

- Family-based treatment programs significantly reduce stress, increase perceived social support from family and friends, and improve family function.

- In general, it is necessary to implement more of the family-oriented psychoeducational treatment program.

- Family members engage in a variety of strategies to protect themselves from the dangers associated with drug use.

- Conceptualizing addiction as a health and social justice issue and providing appropriate interventions can reduce some of the harm experienced by users and family members, thereby fostering sustainable relationships and greater integration and reduction of adverse effects into the environment.

16. Orr, Elliott, Promoting Familyand Barbour, Focused Approaches 2014 within Adult Drug Services: The Potential of the 'Senses Framework.'

17. Tomori et al., "In their Perception, 2014

We are Addicts":

Social Vulnerabilities and Sources of Support for Men Released from Drug Treatment Centers in Vietnam

18. Baker and Kim, Recognizing and 2019 Addressing Elder Abuse in the Primary Care Setting

This is a qualitative study involving eight focus groups and 32 individual interviews.

Applying a family-centered approach to care will provide a greater and strategic feel for drug users.

This research took a sample of 43 male injectable drug users (PWID).

- Families are sources of support ranging from finances, work, and emotional support, but addiction-related family tensions also have adverse psychological effects.

The design of the research is a case study. The sample in this study was 589 subjects.

- Primary care in the form of support to drug abusers is very beneficial, as they feel they are getting more attention and can stop using drugs.

19. Girsang, Susanti and

The Experience of The study Family Members descriptive Helping Young Adult phenomenological Drug Abusers Achieve approach and involved DevelopmentallyAppropriate Levels of Intimacy
Panjaitan, 2019

$$
11 \text { subjects. }
$$

- Internal and external factors may impede the development of adolescent drug abusers

- Family members as the main companions of juvenile drug abusers can also be a complicated burden experienced by 
Devy Mulia Sari, Mochammad Zainal Fatah, and Ira Nurmala. Family’s Role in Helping ...65

\begin{tabular}{|c|c|c|c|c|}
\hline No & Authors & Title & Methods & Results \\
\hline 20. & $\begin{array}{l}\text { Montgomery et } \\
\text { al., } 2020\end{array}$ & $\begin{array}{lr}\text { Peer Social } & \text { Network } \\
\text { Processes } & \text { and } \\
\text { Adolescent } & \text { Health } \\
\text { Behaviors: } & A \\
\text { Systematic Review }\end{array}$ & $\begin{array}{l}\text { Researchers used } \\
\text { systematic review } \\
\text { methods with a } \\
\text { teenager population } \\
\text { (13-18 years old). }\end{array}$ & $\begin{array}{l}\text { families due to drug } \\
\text { abusers in adolescents. } \\
\text { - This research highlight the } \\
\text { importance of psycho- } \\
\text { family education for } \\
\text { families with drug abusers } \\
\text { in their teens. } \\
\text { - Individuals are influenced } \\
\text { by their friends to adopt or } \\
\text { adapt behaviors; and the } \\
\text { relationship between } \\
\text { network popularity and } \\
\text { health behaviors. } \\
\text { - This study highlights the } \\
\text { importance of peer social } \\
\text { networks to build and } \\
\text { determine a set of } \\
\text { individual health behavior } \\
\text { choices. }\end{array}$ \\
\hline
\end{tabular}


Table 1 shows that support in the form of emotional attention such as warmth, caring, or expressions of empathy, can ensure that individuals are surrounded with feelings of love and affection. The drug abuser who gets emotional attention feels confident that he is assisted by the surrounding people (Denomme and Benhanoh, 2017). This study is also in line with research on the recovery process dynamics, which explains the importance of families' role in self-control to occur recovery by drug abusers (Riza, 2018).

Individuals need social support to deal with existing issues. Social support can be an encouragement, trust, confidence, and sharing opportunities, helping to make decisions to help individuals solve problems. A wide range of family support has been received, but most drug abusers have received substantial support. This problem is in accordance with the supportive environment, especially the family environment (Girsang, Susanti and Panjaitan, 2019). The role of the family environment influences the healing process of a person who is drug dependent. This condition is caused because not many of them have a desire to heal that comes from themselves. The majority of drug abusers need support from family (Ghasemi et al., 2018).

Family support in the form of advice or input to drug abusers is the most widely given support. Prevention that family members can do is to provide character planting before drug abusers are involved in problems, especially related issues about drug abuse. This support also fosters a positive character in drug abusers so that inside they create a good character (Bermas and Masooleh, 2011). Individuals who lack support from the family and parents who lack control and supervision will make them experience self-control weaknesses and tend to engage in negative behavior (Kroenke et al., 2006). Drug abusers who undergo rehabilitation will be able to control themselves well if they support the family. Through good self-control, the ability of drug abusers to stop using drugs will be better (Bermas and Masooleh, 2011).

The family's responsibility to other family members to protect and provide support is also critical. Family members who have solid relationships and influences will be a source of strength for individuals to stop abusing drugs (Tomori et al., 2014). When the family does not pay attention or even stay away from drug abusers, then deviant behavior can occur in the individual. Such deviations include not being able to socialize with the environment, disturbed diet, declining academic and non-academic achievement, and the emergence of aggressive attitudes toward drug abusers (Yusay and Canoy, 2019).

Support in the form of attention given by the family in the rehabilitation process will benefit drug abusers. A close relationship between the family and drug abusers will make them feel comfortable and gradually help them get back to health and stop drug abuse. The benefits of family support to prevent drug abuse in one of the family members, among others (Bermas and Masooleh, 2011):

\section{a. Primary prevention}

Prevention is performed on individuals who have not used drugs. This effort is made by asserting that they could be drug abusers if not careful.

\section{b. Secondary prevention}

Prevention to people who have used drugs once in a while has not been a dependency not to fall further.

\section{c. Tertiary prevention}

Prevention is done to people who have dependence (rehabilitation). This effort is made by affirming how not to relapse and return to dependency.

\section{CONCLUSION}

The success of family members in providing social support to drug abusers to stop abusing drugs is by giving selfcontrol to drug abusers. Social support can also be done by maintaining the intensity of relationships with drug abusers. If this action could be done, drug abusers would feel attention and protection. The ability and function of the family in helping self-control drug abusers varies according to how the family responds to drug abusers. The government is expected to consider practical ways of tackling the drug problem in Indonesia. Governmentestablished prevention and recovery programs should also involve families' role to help the successful recovery of drug abusers. 


\section{REFERENCES}

Baker, N. R. and Kim, J. (2019) 'Recognizing and Addressing Elder Abuse in the Primary Care Setting', Advances in Family Practice Nursing. doi: 10.1016/j.yfpn.2018.12.004.

Bash, E. (2015) 'Bahaya Narkoba', PhD Proposal. 10.1017/CBO9781107415324.004.

Bermas, H. and Masooleh, S. M. T. (2011) 'Review and comparison of affective family factors in prevention of drug abuse in view of university masters, mental health specialist and families', in Procedia - Social and Behavioral Sciences. doi: 10.1016/j.sbspro.2011.02.064.

Birtel, M. D., Wood, L. and Kempa, N. J. (2017) 'Stigma and social support in substance abuse: Implications for mental health and well-being', Psychiatry Research. doi: 10.1016/j.psychres.2017.01.097.

Darie, N. (2015) 'Child's Exposures to Emotional Neglect in Drug users Families', Procedia - Social and Behavioral Sciences. doi: 10.1016/j.sbspro.2015.02.312.

Denomme, W. J. and Benhanoh, O. (2017) 'Helping concerned family members of individuals with substance use and concurrent disorders: An evaluation of a family member-oriented treatment program', Journal of Substance Abuse Treatment.

doi: 10.1016/j.jsat.2017.05.012.

Dinilah, M. (2017) Survei BNN 80 Persen Tahu Bahaya Narkoba, Kenapa Kasus Masih Tinggi?, detik.com.

Franco, M. and Carter, S. (2019) 'Discrimination from family and substance use for multiracial individuals', Addictive Behaviors. doi: 10.1016/j.addbeh.2019.01.008.

Ghasemi, A. et al. (2018) 'The effect of an education program based on the family-centered empowerment model on addiction severity among methamphetamine users', Mental Health and Prevention. doi: 10.1016/j.mhp.2018.07.002.

Girsang, Y., Susanti, H. and Panjaitan, R. U. (2019) 'The experience of family members helping young adult drug abusers achieve developmentallyappropriate levels of intimacy', Enfermeria Clinica. doi: 10.1016/j.enfcli.2019.04.130.
Harwin, J. et al. (2019) 'Tensions and contradictions in family court innovation with high risk parents: The place of family drug treatment courts in contemporary family justice', International Journal of Drug Policy. doi: 10.1016/j.drugpo.2018.04.019.

Heaney, C. and Israel, B. A. (2018) Social networks and social support. In $\mathrm{K}$. Glanz, B. K. Rimer, \& K. Viswanath (Eds.), Health behavior and health education: Theory, research, and practice, Psychological Review. doi: 10.1016/S0033-3506(49)81524-1.

Inassa, I. (2019) 'KEGIATAN TES URINE SEBAGAI UPAYA P4GN DI INSTANSI PEMERINTAH OLEH BNNP JAWA TIMUR', Medical Technology and Public Health Journal. doi: 10.33086/mtphj.v3i2.679.

Ingram, H. (2005) 'Family values', International Journal of Contemporary Hospitality Management. doi: 10.1108/09596110510591945.

Jackson, L. A. et al. (2011) 'Challenges and opportunities to integrating family members of injection drug users into harm reduction efforts within the Atlantic Canadian context', International Journal of Drug Policy. doi: 10.1016/j.drugpo.2011.05.011.

Kroenke, C. H. et al. (2006) 'Social networks, social support, and survival after breast cancer diagnosis', Journal of Clinical Oncology. doi: 10.1200/JCO.2005.04.2846.

Li, J. and Ma, M. (2018) 'The analysis of a drug transmission model with family education and public health education', Infectious Disease Modelling. doi: 10.1016/j.idm.2018.03.007.

Li, L. et al. (2013) 'Mental health and family relations among people who inject drugs and their family members in Vietnam', International Journal of Drug Policy. doi: 10.1016/j.drugpo.2013.06.007.

McCann, T. V. and Lubman, D. I. (2018) 'Help-seeking barriers and facilitators for affected family members of a relative with alcohol and other drug misuse: A qualitative study', Journal of Substance Abuse Treatment. doi: 10.1016/j.jsat.2018.07.005.

Montgomery, S. C. et al. (2020) 'Peer social network processes and adolescent health behaviors: A systematic review', Preventive 
Medicine.

doi:

10.1016/j.ypmed.2019.105900.

Nurhidayati, N. and Nurdibyanandaru, D. (2014) 'Hubungan antara dukungan sosial keluarga dengan self esteem pada penyalahguna narkoba yang direhabilitasi', Psikologi Kepribadian Dan Sosial.

Orr, L. C., Elliott, L. and Barbour, R. S. (2014) 'Promoting family-focused approaches within adult drug services: The potential of the "Senses Framework", International Journal of Drug Policy. doi: 10.1016/j.drugpo.2014.04.011.

Peraturan Pemerintah No. 25 Tahun 2011 tentang Pelaksanaan Wajib Lapor Penyalahguna Narkoba (2011). Indonesia.

Rasdianah, R. and Nur, F. (2018) 'EFEKTIVITAS PELAKSANAAN REHABILITASI MEDIS TERHADAP PECANDU DAN KORBAN PENYALAHGUNAAN NARKOTIKA DI PROVINSI GORONTALO', Jurisprudentie: Jurusan Ilmu Hukum Fakultas Syariah dan Hukum. doi: 10.24252/jurisprudentie.v5i2.6282.

Ritanti et al. (2017) 'A phenomenological study of families with drug-using children living in the society', International Journal of Pediatrics and Adolescent Medicine. doi: 10.1016/j.ijpam.2017.04.001.

Riza, W. L. (2018) 'DINAMIKA PSIKOLOGIS PADA MANTAN PECANDU NAPZA YANG SEDANG MENJALANI PROGRAM SUBSTITUSI ORAL METADON (STUDI KASUS)', PSYCHOPEDIA : Jurnal Psikologi Universitas Buana Perjuangan Karawang. doi: 10.36805/psikologi.v3i2.486.

Rowe, C. L. (2012) 'Family Therapy for Drug Abuse: Review and Updates 20032010', Journal of Marital and Family Therapy. doi: 10.1111/j.17520606.2011.00280.x.

Sanders, M. R. (2000) 'Community-based parenting and family support interventions and the prevention of drug abuse', in Addictive Behaviors. doi: 10.1016/S0306-4603(00)00128-3.
Sari Wulan Rohmah (2019) 'Sinergitas Kerjasama Antara Bnn Dan Polri Dalam Proses Penyidikan Tindak Pidana Narkotika', Faculty of law.

Smestha, B. R. (2015) 'Pengaruh selfesteem dan dukungan sosial terhadap resiliensi mantan pecandu narkoba', Fakultas Psikologi Universitas Islam Negeri Syarif Hidayatullah Jakarta.

Tomori, C. et al. (2014) " "In their perception we are addicts": Social vulnerabilities and sources of support for men released from drug treatment centers in Vietnam', International Journal of Drug Policy. doi: 10.1016/j.drugpo.2014.04.012.

Undang-Undang Nomor 35 Tahun 2009 tentang Narkotika (2009). Indonesia.

Undang-Undang Republik Indonesia Nomor 36 Tahun 2009 tentang Kesehatan (2009). Indonesia.

United Nations Office on Drugs and Crime (2018) World Drug Report 2018, United Nations Office on Drugs and Crime. doi: 10.1080/00909887909365203.

Yunitasari, P. (2018) 'PENGARUH DUKUNGAN KELUARGA TERHADAP KEKAMBUHAN PECANDU NARKOBA REHABILITASI DI RSJ GRHASIA YOGYAKARTA', Medika Respati : Jurnal Ilmiah Kesehatan. doi: 10.35842/mr.v13i4.198.

Yusay, C. T. C. and Canoy, N. A. (2019) 'Healing the hurt amid the drug war: Narratives of young urban poor Filipinos in recovering families with parental drug use', International Journal of Drug Policy. doi: 10.1016/j.drugpo.2018.10.009.

Zamani, Z. A. et al. (2014) 'Family Functioning, Cognitive Distortion and Resilience among Clients under Treatment in Drug Rehabilitation Centres in Malaysia', Procedia - Social and Behavioral Sciences. doi: 10.1016/j.sbspro.2014.04.401.

Zhang, S. et al. (2019) 'The impacts of family treatment drug court on child welfare core outcomes: A metaanalysis', Child Abuse and Neglect. doi: 10.1016/j.chiabu.2018.10.014. 